\title{
Influence of copper composition and reaction temperature on the properties of CZTSe thin films
}

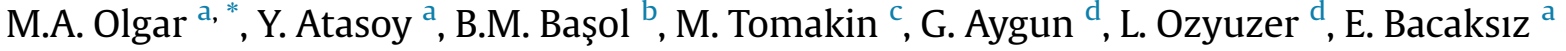 \\ a Department of Physics, Faculty of Sciences, Karadeniz Technical University, 61080, Trabzon, Turkey \\ b Encore Solar, 6541 Via Del Oro, Suite B, San Jose, CA, 95119, USA \\ ${ }^{\mathrm{c}}$ Department of Physics, Recep Tayyip Erdogan University, Rize, Turkey \\ d Izmir Inst Technol, Dept Phys, TR-35430, Izmir, Turkey
}

\section{A R T I C L E I N F O}

\section{Article history:}

Received 6 January 2016

Received in revised form

19 April 2016

Accepted 28 April 2016

Available online 6 May 2016

\section{Keywords:}

$\mathrm{Cu}_{2} \mathrm{ZnSnSe}_{4}$ (CZTSe)

Sputtering

Copper composition

Reaction temperature

Thin film solar cells

\begin{abstract}
A B S T R A C T
In this study $\mathrm{Cu}_{2} \mathrm{ZnSnSe}_{4}$ (CZTSe) compound layers were grown using a two-stage technique that involved deposition of metallic precursors ( $\mathrm{Cu}, \mathrm{Zn}$, and $\mathrm{Sn}$ ) and Se in the first stage, followed by reaction of all the species at temperatures between $525{ }^{\circ} \mathrm{C}$ and $600{ }^{\circ} \mathrm{C}$, during the second stage of the process Two sets of samples, one with $\mathrm{Cu}$-poor, $\mathrm{Zn}$-rich and the other with $\mathrm{Cu}$-rich, $\mathrm{Zn}$-rich compositions, were prepared and their structural, optical and electrical properties were measured. XRD analyses showed the characteristic peaks of CZTSe regardless of the $\mathrm{Cu}$ content and the processing temperature. However, for samples reacted at temperatures of $575^{\circ} \mathrm{C}$ and $600^{\circ} \mathrm{Ca} \mathrm{Cu}_{2-\mathrm{x}} \mathrm{Se}$ secondary phase separation was detected for all films suggesting that the reaction temperatures should be limited to values below $575{ }^{\circ} \mathrm{C}$ in a twostage process such as ours. Excessive Sn loss was also present in samples processed at the highest temperatures. Raman scattering measurements confirmed formation of the CZTSe kesterite structure, and also indicated a small ZnSe phase, which could not be detected by XRD. Scanning electron micrographs demonstrated dense film structure with the Cu-rich films having smoother morphology. Optical characterization showed that increasing the $\mathrm{Cu}$ content in the compound layers caused a reduction in the optical band gap values due to increased interaction between the $\mathrm{Cu}-3 \mathrm{~d}$ orbital electrons and the Se-4p orbital electrons. Electrical measurements showed that the carrier concentration increased with $\mathrm{Cu}$ content.
\end{abstract}

() 2016 Elsevier B.V. All rights reserved.

\section{Introduction}

$\mathrm{Cu}_{2} \mathrm{ZnSnSe}_{4}$ (CZTSe) is an attractive absorber material for the fabrication of thin film solar cells. It is being developed as an alternative to CuInGaSe 2 (CIGS), which has yielded over $20 \%$ efficient devices [1], but suffers from the fact that In and Ga are scarce materials. The constituent elements of CZTSe are much more abundant [2], and the compound has high optical absorption coefficients, making it suitable for thin film photovoltaic applications [3].

Deposition of CZTSe thin films has been carried out utilizing both non-vacuum and vacuum techniques. For example, electrodeposition has been widely used [4-6]. Spin coating yielded the highest efficiency (12.6\%) devices to date employing absorbers

\footnotetext{
* Corresponding author.

E-mail address: mehmetaliolgar@gmail.com (M.A. Olgar).
}

containing both Se and S [7]. Qeslati et al. demonstrated $10.4 \%$ efficient cells using films obtained by the selenization of sputtered metallic films in an $\mathrm{H}_{2} \mathrm{Se}$ atmosphere [8]. J. Marquez-Prieto et al. reacted sputtered $\mathrm{Cu}-\mathrm{Zn}-\mathrm{Sn}$ metallic films with evaporated Se layers at temperatures between $380{ }^{\circ} \mathrm{C}$ and $550{ }^{\circ} \mathrm{C}$ to form the compound [9]. Repins et al. studied the co-evaporation technique for CZTSe film growth [10]. Films were also grown by spray deposition and pyrolysis $[11,12]$. In the present study, CZTSe films were prepared by a two-stage technique that involved reaction of sputtered/evaporated precursor stacks at elevated temperatures; and the impact of $\mathrm{Cu}$ content and the reaction temperature on the structural, optical, and electrical properties of the resulting compound layers was studied.

\section{Experimental}

CZTSe thin films were prepared by a two-stage process. During the first stage, metallic films comprising $\mathrm{Cu}, \mathrm{Zn}$ and $\mathrm{Sn}$ were 
deposited onto unheated molybdenum (Mo) coated soda lime glass (SLG) substrates via DC magnetron sputtering from high-purity (5 N Cu, $4 \mathrm{~N} \mathrm{Zn,} \mathrm{and} 5 \mathrm{~N} \mathrm{Sn}$ ) targets, and thermal evaporation was used to form a Se cap over the sputter deposited films, forming $\mathrm{Cu}-\mathrm{Zn}-\mathrm{Sn} / \mathrm{Se}$ precursor stacks. The Se source was $5 \mathrm{~N}$ pure Se shots evaporated out of a Mo boat. The base pressures of the sputtering chamber and the thermal evaporation system were about $10^{-6}$ mbar and $10^{-5}$ mbar, respectively. During deposition the chamber pressures were about $10^{-3}$ mbar and $10^{-4}$ mbar for the sputtering and evaporation processes, respectively. Thicknesses of the sputtered metallic precursors were calibrated according to the sputtering rate of each element, which were determined through calibration runs and thickness measurements using a Veeco DEKTAK 150 surface profilometer. Thicknesses of the Se cap layers were monitored and controlled using an Inficon SQM 160 crystal controller/monitor installed in the thermal evaporator. It should be noted that sputtering is a versatile technique for controlling the properties of materials by modifying their composition and by manipulating the arrangement of atoms. Since these are issues beyond the scope of the present work readers are referred to fundamental studies on sputtered metal films, where the authors followed in situ the growth of the layers during the dc sputtering process $[13,14]$.

In two-stage processing it is possible to change the properties of the resulting compound layers by changing the nature of the precursor layers, such as the deposition technique and/or sequence of the various species within the precursor stack. For example, in forming CIGS type films through two-stage processing researchers had found that the order of deposition for $\mathrm{Cu}$ and In determined the morphology of the compound layer after the reaction step [15]. In this work we used a $\mathrm{Cu} / \mathrm{Sn} / \mathrm{Zn} / \mathrm{Cu} / \mathrm{Se}$ deposition sequence for the precursor stacks, which is different from much of the previously reported work. Yoo et al. had investigated secondary phase formation in CZTSe films by studying $\mathrm{Mo} / \mathrm{Cu} / \mathrm{Sn} / \mathrm{Se}, \mathrm{Mo} / \mathrm{Sn} / \mathrm{Cu} / \mathrm{Se}, \mathrm{Mo} /$ $\mathrm{Cu} / \mathrm{Zn} / \mathrm{Se}, \mathrm{Mo} / \mathrm{Zn} / \mathrm{Cu} / \mathrm{Se}, \mathrm{Mo} / \mathrm{Sn} / \mathrm{Zn} / \mathrm{Se}$, and $\mathrm{Mo} / \mathrm{Zn} / \mathrm{Sn} / \mathrm{Se}$ partial stacks by time-resolved XRD measurements as these stacks were heated up to a temperature of $550{ }^{\circ} \mathrm{C}$ [16]. The results showed that the tendency of reaction between various pairs of elements could be expressed

as

$\mathrm{Sn}-\mathrm{Se}<\mathrm{Zn}-\mathrm{Sn}<\mathrm{Cu}-\mathrm{Sn}<\mathrm{Cu}-\mathrm{Se}<\mathrm{Cu}-\mathrm{Zn}<\mathrm{Zn}-\mathrm{Se}$, meaning $\mathrm{Zn}-$ Se reaction was the most favorable (taking place at the lowest temperature) followed by the reaction of $\mathrm{Cu}$ with $\mathrm{Zn}$, Se and Sn, respectively. In our stack formation, by distributing $\mathrm{Cu}$ in the form of two sub-layers we attempted to place naturally more reactive species next to each other. Also the volatile $\mathrm{Zn}$ was kept under a $\mathrm{Cu}$ layer that it could easily react with.

The target thickness values were 165,230 , and $1300 \mathrm{~nm}$ for the $\mathrm{Zn}$, Sn and Se layers, respectively. The total targeted $\mathrm{Cu}$ thickness was $175 \mathrm{~nm}$ and $225 \mathrm{~nm}$ for the $\mathrm{Cu}$-poor and Cu-rich films, respectively. Nearly $70 \%$ of the $\mathrm{Cu}$ target thickness was deposited over Mo, and 30\% over the $\mathrm{Zn}$ layer. The target thickness for Se represents a value that is about $40 \%$ in excess of what is necessary to form the compound, because it was determined through calibration experiments that this excess was needed for our reactor setup to avoid excessive loss of Se during the annealing step, at least for reaction temperatures below $600{ }^{\circ} \mathrm{C}$. We also added $\mathrm{Sn}$ (II)Se powder with $4 \mathrm{~N}$ purity to the area around the sample on the sample holder to establish an overpressure of Sn during the annealing process to help reduce $S n$ loss from the stacks at elevated temperatures.

During the second stage of the process the precursor stacks were annealed for $15 \mathrm{~min}$ in a tube furnace in a static $5 \% \mathrm{H}_{2}+95 \% \mathrm{Ar}$ atmosphere at four different temperatures; 525, 550, 575, and $600{ }^{\circ} \mathrm{C}$. The tube was pumped down and then filled back to atmospheric pressure with the inert gas mixture several times to get rid of the air before the reaction was initiated. For simulating a rapid thermal process, the tube furnace was first heated to the reaction temperature and the samples were then rapidly pushed into the hot zone. The estimated ramping rate of the temperature in these experiments was about $5{ }^{\circ} \mathrm{C} / \mathrm{s}$. At the end of the reaction period samples were pulled back into the cool zone of the furnace under flowing inert gas.

In this manuscript the $\mathrm{Cu}$-poor samples are identified as A525, A550, A575, and A600, and the Cu-rich samples are identified as $\mathrm{B} 525, \mathrm{~B} 550, \mathrm{~B} 575$, and B600. The numerical values indicate the reaction temperature. For example, A525 implies a compositionally $\mathrm{Cu}$-poor sample that was obtained by annealing a precursor layer at $525{ }^{\circ} \mathrm{C}$ for $15 \mathrm{~min}$. It should be noted that the "A" group samples listed above were all produced from the same precursor stack, only the reaction temperature being different. The same is true for the "B" group samples.

Since the CZTSe thin films were grown on conductive and nontransparent substrates, optical transmission of the films could only be performed after they were removed from their substrates with a mechanical transfer method as previously utilized by Basol [17]. This technique involved placement of a transparent epoxy on top of a CZTSe layer, placement of a piece of $3 \mathrm{~mm}$ thick transfer glass over the epoxy forming a sandwich layer, and after curing of the epoxy for $24 \mathrm{~h}$, mechanically transferring the CZTSe layer onto the transfer glass by applying a sudden force to the transfer glass away from the substrate of the CZTSe layer. The glass/transparent epoxy/CZTSe samples prepared in this fashion could then be used in optical transmission as well as in-plane resistivity measurements.

The crystalline structure and the structural quality of the films were determined by XRD measurements using a Rigaku SmartLab diffractometer with a CuK $\alpha$ radiation source $(\lambda=1.5405 \AA)$ in the range of $2 \theta=20-80^{\circ}$ at room temperature. The phase compositions of the CZTSe films were analyzed by Raman scattering measurements (Renishaw Invia confocal Raman, Model 614E68) excited with a laser at a wavelength of $532 \mathrm{~nm}$. The morphological and compositional analyses were performed by a Jeol JSM 6610 scanning electron microscope (SEM) and an Oxford Instruments Inca Xact energy dispersive X-ray spectroscopy (EDX) system. The optical transmittance spectra were obtained using a Dongwoo Optron spectrophotometer in the wavelength range of 1000-1800 nm. The electrical characterization was performed using Van der Pauw method at room temperature. Electrical contacts in the Van der Pauw samples were made by $\mathrm{Ag}$ paste dots of about $1 \mathrm{~mm}$ diameter. The four electrical contacts were placed at the four corners of the $1 \mathrm{~cm} x 1 \mathrm{~cm}$ square samples.

\section{Results and discussion}

The EDX analysis data obtained from the $\mathrm{Cu}$-poor and $\mathrm{Cu}$-rich CZTSe thin films are summarized in Table 1 . These results confirm that the composition of the " $\mathrm{A}$ " type films is $\mathrm{Cu}$-poor and $\mathrm{Zn}$-rich, whereas the composition of " $\mathrm{B}$ " type films is both $\mathrm{Cu}$ and $\mathrm{Zn}$ rich, as targeted. However, there are also some clear trends that can be seen from this data. For example, as the reaction temperature goes from $575{ }^{\circ} \mathrm{C}$ to $600{ }^{\circ} \mathrm{C}$, the $\mathrm{Zn} / \mathrm{Sn}$ ratio reaches its maximum value for both the $\mathrm{Cu}$-rich and the $\mathrm{Cu}$-poor samples indicating excessive

Table 1

Atomic ratios in CZTSe thin films as determined by EDX analysis.

\begin{tabular}{lllllllll}
\hline Atomic ratio & A525 & A550 & A575 & A600 & B525 & B550 & B575 & B600 \\
\hline $\mathrm{Cu} /(\mathrm{Zn}+\mathrm{Sn})$ & 0.75 & 0.84 & 0.74 & 0.94 & 1.19 & 1.11 & 1.12 & 1.29 \\
$\mathrm{Zn} / \mathrm{Sn}$ & 1.03 & 1.21 & 1.38 & 2.43 & 1.16 & 1.10 & 1.34 & 1.37 \\
$\mathrm{Se} /$ Metal & 0.94 & 0.95 & 0.92 & 0.80 & 0.86 & 0.87 & 0.85 & 0.79 \\
\hline
\end{tabular}


Sn loss at this high temperature despite the fact that we established some degree of $\mathrm{Sn}$ overpressure around the sample holder by placing Sn(II)Se powder. Similarly, the Se/metal ratio goes down at this high reaction temperature signifying excessive Se loss, possibly in the form of SnSe. Clearly, for device quality films obtained by the two-stage process the reaction temperatures should be limited to values less than $575{ }^{\circ} \mathrm{C}$, especially if the reaction boat is not in the form of a sealed box with very small volume.

The XRD patterns of the CZTSe thin films grown at various reaction temperatures are presented in Fig. 1. The three most intensive peaks in the data of Fig. 1 are at $2 \theta$ values of around $27.15^{\circ}$, $45.10^{\circ}$ and $53.45^{\circ}$, and they were indexed to (112), (220/204), and (312/116) planes of kesterite CZTSe structure, respectively (JCPDS 00-052-0868). The expected locations of the lower intensity characteristic peaks for the CZTSe phase are also shown in Fig. 1 with the symbol $\left({ }^{*}\right)$. As can be seen from this data, regardless of the $\mathrm{Cu}$ content and the reaction temperatures studied here, all samples display the characteristic CZTSe peaks, indicating that a reaction temperature of $525^{\circ} \mathrm{C}$ and a reaction time of $15 \mathrm{~min}$ are adequate to
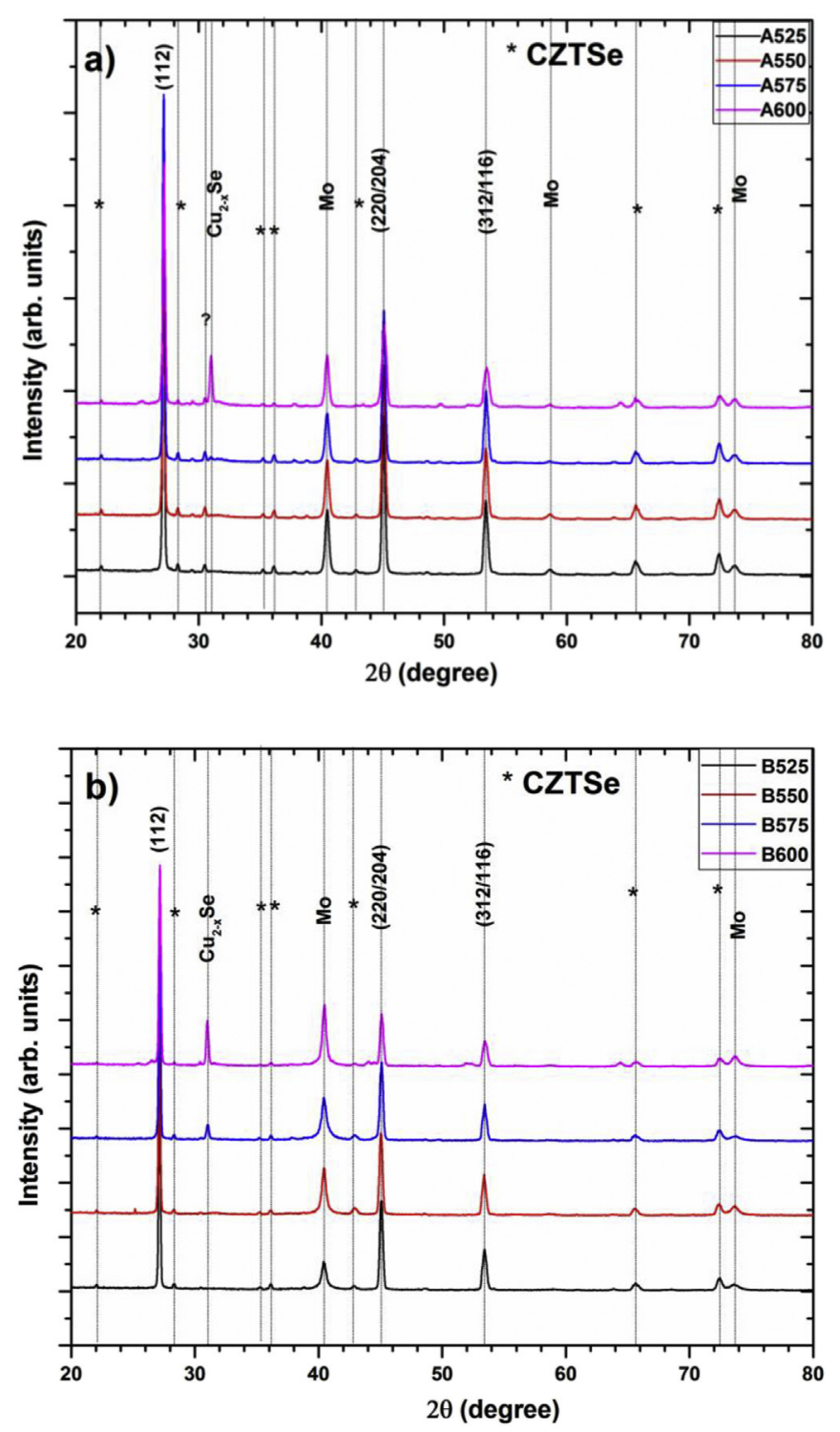

Fig. 1. X-ray diffraction patterns obtained from; a) "A" type, and b) "B" type CZTSe thin films. form the compound in a two-stage process utilizing a temperature rise rate of about $5{ }^{\circ} \mathrm{C} /$ second. In addition to the characteristic CZTSe peaks, some minor peaks can also be observed in the data of Fig. 1 associated with phases such as $\mathrm{Cu}_{2-\mathrm{x}} \mathrm{Se}$ (JCPDS 00-06-0680), Mo (JCPDS 01-089-5023) which is due to the substrate, and one minor unidentified peak (?) at the $2 \theta$ value of $30.47^{\circ}$. This unidentified peak can also be seen in the XRD data of Babu et al. obtained from co-evaporated films [18]. We believe that this minor peak may be associated with orthorhombic SnSe (JCPDS 00-048$1224)$, which has its most intense (111) peak at $30.463^{\circ}$. Presence of $\mathrm{Cu}_{2-x} \mathrm{Se}$ in the A575, A600, B575, and B600 samples indicates excessive $\mathrm{Sn}$ loss at the reaction temperature of $575^{\circ} \mathrm{C}$ and above, which results in the separation of a Cu-selenide secondary phase in the compound layers, despite the fact that the EDX data of Table 1 shows an overall Cu-poor composition for the A575 and A600 samples. As expected, the $\mathrm{Cu}_{2-\mathrm{x}} \mathrm{Se}$ peak in the $\mathrm{Cu}$-rich $\mathrm{B} 575$ sample is much more pronounced than in the $\mathrm{Cu}$-poor A575 sample. These results demonstrate that the highest safe reaction temperature to be used in our present technique is around $550{ }^{\circ} \mathrm{C}$ to avoid excessive $\mathrm{Cu}$-selenide phase separation.

The full-width-at-half-maximum (FWHM) values obtained from the (112) peaks in Fig. 1 are shown in Fig. 2 for samples reacted at $525-550^{\circ} \mathrm{C}$. Data for the higher temperature films are not included in this figure because XRD results showed appreciable phase separation in these samples. It should be noted that phases such as $\mathrm{Cu}_{\mathrm{x}} \mathrm{Se}$ can introduce error in FWHM measurements since they have strong peaks close to the (112) peak of CZTSe. Also stresses introduced by secondary phases in the plane of the film can cause changes in the observed FWHM values. As can be seen from the data of Fig. 2, the XRD peaks are clearly sharper for "B" type $\mathrm{Cu}$-rich samples compared to the "A" type Cu-poor samples and the FWHM values get smaller for both types of samples as the reaction temperature increases from $525{ }^{\circ} \mathrm{C}$ to $550{ }^{\circ} \mathrm{C}$. This behavior is consistent with the fact that crystallite size, which is one of the factors that can affect the FWHM value, is expected to increase with increased $\mathrm{Cu}$ concentration and increased reaction temperature. It should be noted that $\mathrm{Cu}$-rich compositions as well as higher temperatures promote grain growth in CZTSe type compounds, i.e. kesterites, as well as chalcopyrites such as CIGS, due to the fluxing action of low melting point $\mathrm{Cu}-$ Se species which provide a semiliquid environment for crystals to grow into and fuse together

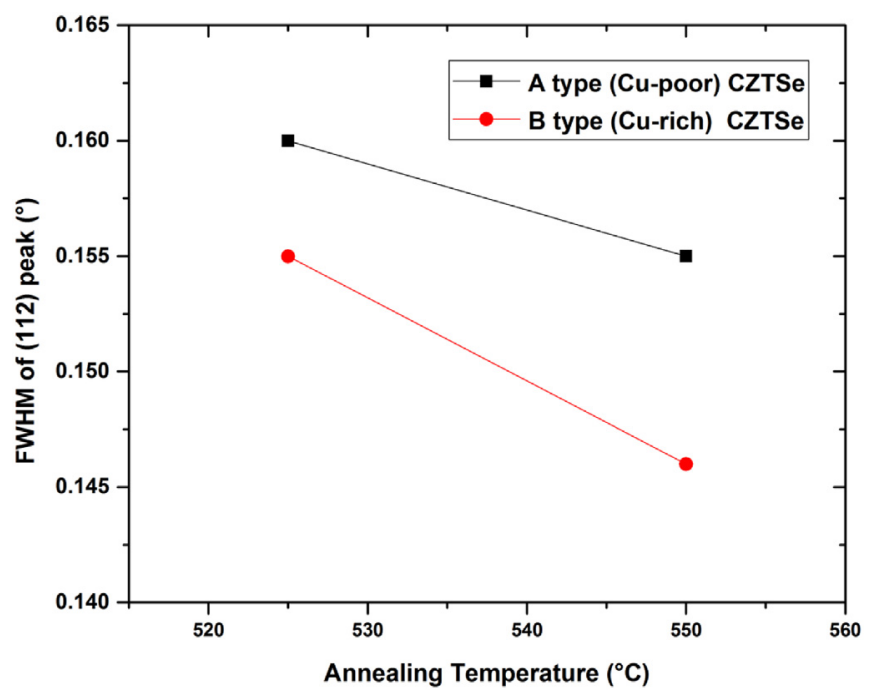

Fig. 2. Full-width-at-half-maximum (FWHM) of the (112) XRD peaks of A525, A550, B525, and B550 CZTSe thin films. 
during the reaction period [19].

Raman spectra of the CZTSe films are necessary to confirm the presence of the kesterite phase since portions of the XRD patterns for the CZTSe (JCPDS 00-052-0868), $\mathrm{Cu}_{2} \mathrm{SnSe}_{3}$ (CTSe) (JCPDS 01072-8034), and ZnSe (JCPDS 01-071-5977) phases overlap. As can be seen from the Raman data presented in Fig. 3, irrespective of the $\mathrm{Cu}$ content and the reaction temperature, the spectra of our compound layers are dominated by the two peaks located at $195-196 \mathrm{~cm}^{-1}$ and $172-173 \mathrm{~cm}^{-1}$. Both of these peaks are attributed to the kesterite CZTSe phase. The lower intensity peak located at $232-233 \mathrm{~cm}^{-1}$ is also due to the CZTSe phase [8]. The other low intensity peak at $251-252 \mathrm{~cm}^{-1}$ is probably related to cubic $\mathrm{ZnSe}$ and it is present in both "A" and "B" type films, which are both $\mathrm{Zn}$ rich. Apart from the above mentioned peaks, the "B" type films (B575 and B600) show traces of $\mathrm{Cu}_{2-\mathrm{x}} \mathrm{Se}$ phase at $261-262 \mathrm{~cm}^{-1}$, which is expected for their $\mathrm{Cu}$-rich composition and is supported by the XRD data presented before and the work by others [20]. Although the $\mathrm{Cu}_{2-\mathrm{x}} \mathrm{Se}$ phase was observed in the XRD pattern of A600 (see Fig. 1(a)) we could not identify a clear peak for this
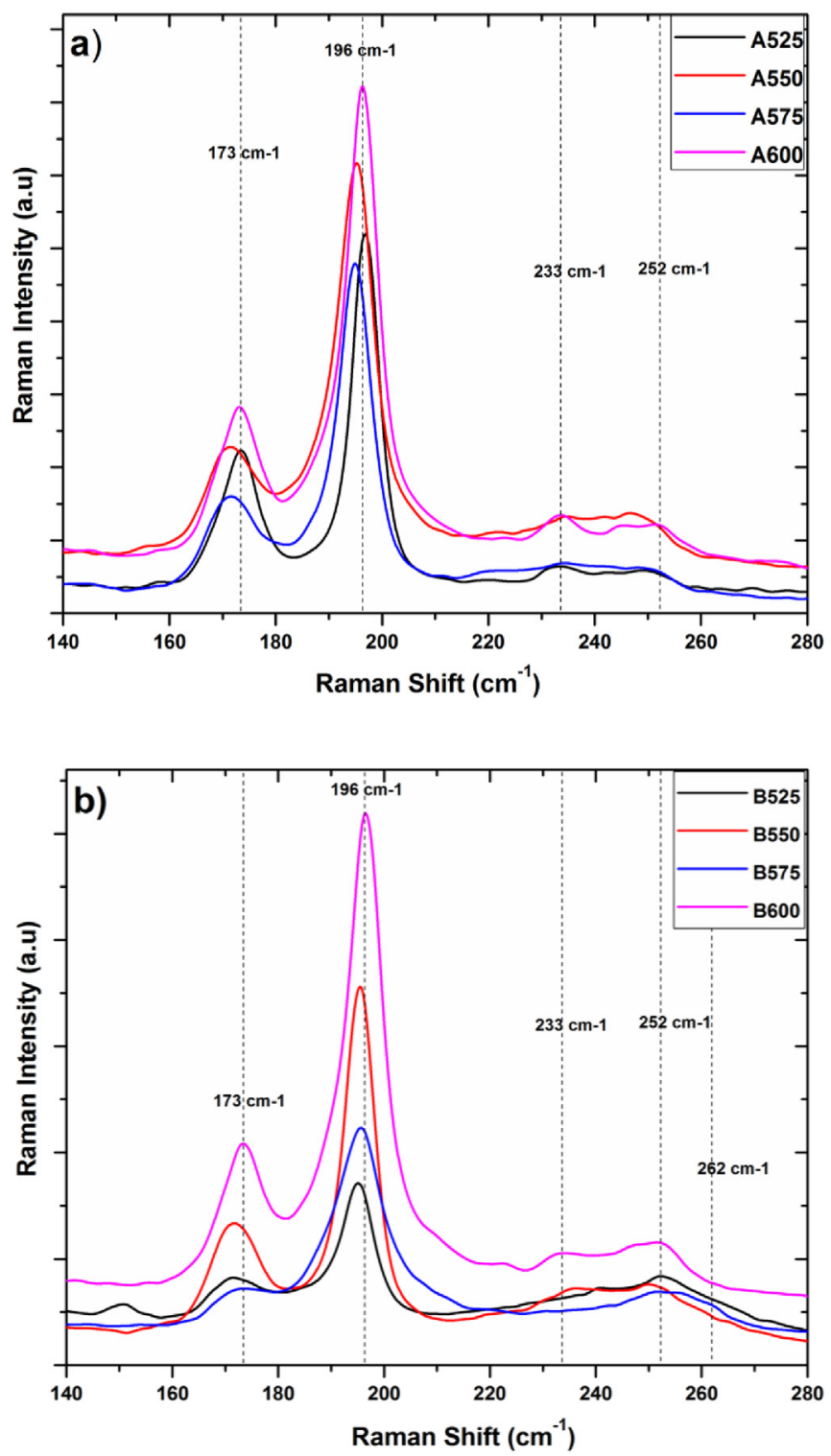

Fig. 3. Raman spectroscopy of A type (Cu-poor) and B type (Cu-rich) CZTSe thin films. sample through the Raman data. The width of the main peak at 195-196 $\mathrm{cm}^{-1}$ provides information about the ordering/disordering of the $\mathrm{Cu}$ and $\mathrm{Zn}$ atoms in the CZTSe structure. As can be seen from the data of Table 2, smaller width values are observed for the " $A$ " type samples. It is known that increasing the ordering of the atoms decreases the width of the main peak [21]. Thus, "A" type films should have more ordered CZTSe structure as compared with B type films according to the values shown in Table 2. These results are in agreement with some of the prior studies. For example, J. Marquez et al. reported that in their studies of $\mathrm{Cu}$-rich and $\mathrm{Cu}$-poor kesterite films the layers with $\mathrm{Cu}$ content were found to be more ordered [22] and this was consistent with the findings of Paris et al. [23] who observed that Cu-poor CZTS samples with predominant $\left[\mathrm{V}_{\mathrm{Cu}}+\mathrm{Zn}_{\mathrm{Cu}}\right]$ defect clusters presented an increase in the ordering of the $\mathrm{Cu}$ and $\mathrm{Zn}$ cations in the $2 \mathrm{c}$ and $2 \mathrm{~d}$ positions. It is interesting to note that the A600 sample of Table 2 displayed the smallest peak width value. It is possible that in this sample when the secondary $\mathrm{Cu}_{2-\mathrm{x}} \mathrm{Se}$ separates, the remaining phase is more $\mathrm{Cu}$-poor and actually more ordered. In addition to its impact on crystal structure, $\left[\mathrm{V}_{\mathrm{Cu}}+\mathrm{Zn}_{\mathrm{Cu}}\right]$ defect clusters also influence the optical properties of the films. Increasing of the $\left[\mathrm{V}_{\mathrm{Cu}}+\mathrm{Zn}_{\mathrm{Cu}}\right]$ defect clusters give rise to downshift of the valance band maximum and upshift of the conduction band minimum. Chen et al. proposed from theoretical calculations that $\mathrm{Cu}$-poor and $\mathrm{Zn}$-rich compositions are favorable for better performing CZTS(e)-based solar cells since this composition favors the formation of the $\left[\mathrm{V}_{\mathrm{Cu}}+\mathrm{Zn}_{\mathrm{Cu}}\right]$ clusters [24].

The SEM images taken from the surface of the " $A$ " and " $B$ " type films are shown in Fig. 4. Although some of the samples show somewhat non-uniform and inhomogeneous surface, they as a whole display a rather dense structure regardless of the composition and the reaction temperature. For the "A" type films higher reaction temperatures improved fusion between the surface structures and yielded more compact films. Increasing the reaction temperature yielded similar results for the "B" type films also. As the annealing temperature increased, cracks within the layers disappeared, and the surface structures became larger and more compact.

Fig. 5 shows the SEM micrographs taken from the cross-sections of the compound films. Most of the films show a high degree of surface roughness. Comparing the A525 data with that of B525 demonstrates the difference between the $\mathrm{Cu}$-poor and $\mathrm{Cu}$-rich layers grown at a relatively low temperature. Unlike A525, the B525 film shows very dense, relatively smooth molten-like morphology, which continues through sample B600. The "A" type samples display a rougher morphology in general with nonuniform surface structure size.

The previously reported optical bandgap values for CZTSe thin films show variations, which may be due to stoichiometric differences and presence of undesired secondary phases [25], [26]. Most of the optical analyses, however, suggest a band gap value in the range of $0.9-1.0 \mathrm{eV}$ [27]. In our studies we used the CZTSe layers transferred onto transfer glass sheets by the mechanical peeling technique described before, to take transmission/reflection measurements. The optical band gap of the " $\mathrm{A}$ " and "B" type films were calculated from the equation (1) [28]:

Table 2

Width of the main Raman peak of the CZTSe thin films.

\begin{tabular}{|c|c|c|c|c|c|c|c|c|}
\hline \multirow[t]{2}{*}{ Sample ID } & \multicolumn{4}{|c|}{$\mathrm{Cu}$-poor } & \multicolumn{4}{|c|}{ Cu-rich } \\
\hline & A525 & A550 & A575 & A600 & B525 & B550 & B575 & B600 \\
\hline Peak width $\left(\mathrm{cm}^{-1}\right)$ & 6.3 & 6.4 & 7.1 & 5.5 & 7.1 & 6.5 & 8.0 & 6.5 \\
\hline
\end{tabular}



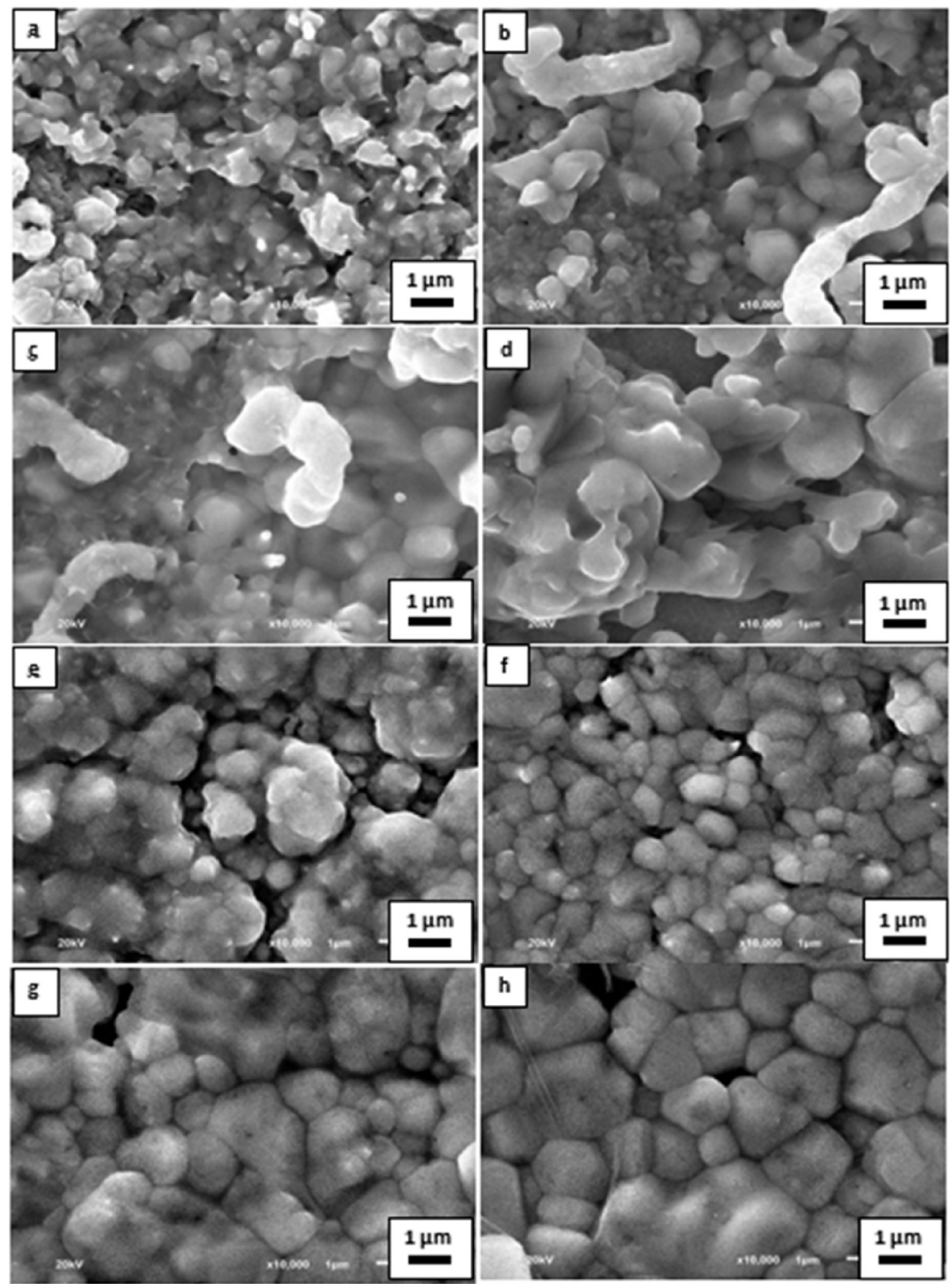

Fig. 4. SEM top views of; a) A525, b) A550, c) A575, d) A600, e) B525, f) B550, g) B575, and h) B600 samples.

$\alpha h v=\mathrm{A}(\mathrm{h} v-\mathrm{Eg})^{1 / 2}$

where $\alpha$ is optical absorption coefficient, $\mathrm{A}$ is a constant, and $\mathrm{E}_{\mathrm{g}}$ is the optical band gap. The band gap values were obtained by extrapolating the $(\alpha h \nu)^{2}$ versus photon energy (hu) plots to intercept the horizontal photon energy axis.

The optical band gap values of our CZTSe thin films show variations with respect to the $\mathrm{Cu} /(\mathrm{Zn}+\mathrm{Sn})$ ratios. The band gap of "A" type films change from 0.90 to $0.93 \mathrm{eV}$, and the band gap of " $\mathrm{B}$ " type films change from 0.84 to $0.90 \mathrm{eV}$ Fig. 6 shows two typical band gap data collected for the A525 and B525 samples.

Table 3 shows the band gap values obtained from the samples grown at 525 and $550{ }^{\circ} \mathrm{C}$, which were found to be the "safe" reaction temperatures in terms of compound formation without excessive secondary phase separation. Comparing the data for the "A" and "B" type films, it can be seen that as the $\mathrm{Cu} /(\mathrm{Zn}+\mathrm{Sn})$ atomic ratio increases, the band gap values go down. It has been reported that the valance band of $\mathrm{Cu}-\mathrm{Se}$ based semiconductors is perturbed by the interaction of $\mathrm{Cu}-3 \mathrm{~d}$ orbital electrons and $\mathrm{Se}-4 \mathrm{p}$ orbital electrons. The interaction between the $\mathrm{Cu}-3 \mathrm{~d}$ orbitals and Se-4p orbitals pushes the valance band position to higher energy levels which gives rise to the reduction in the effective $E_{g}$ Ref. [29]. Therefore, decreasing $\mathrm{Cu}$ content in the CZTSe thin films leads to weaker interaction of $\mathrm{Cu}-\mathrm{Se}$, and thus higher band gap value. Also as mentioned before, in kesterites with Cu-poor composition, easy 

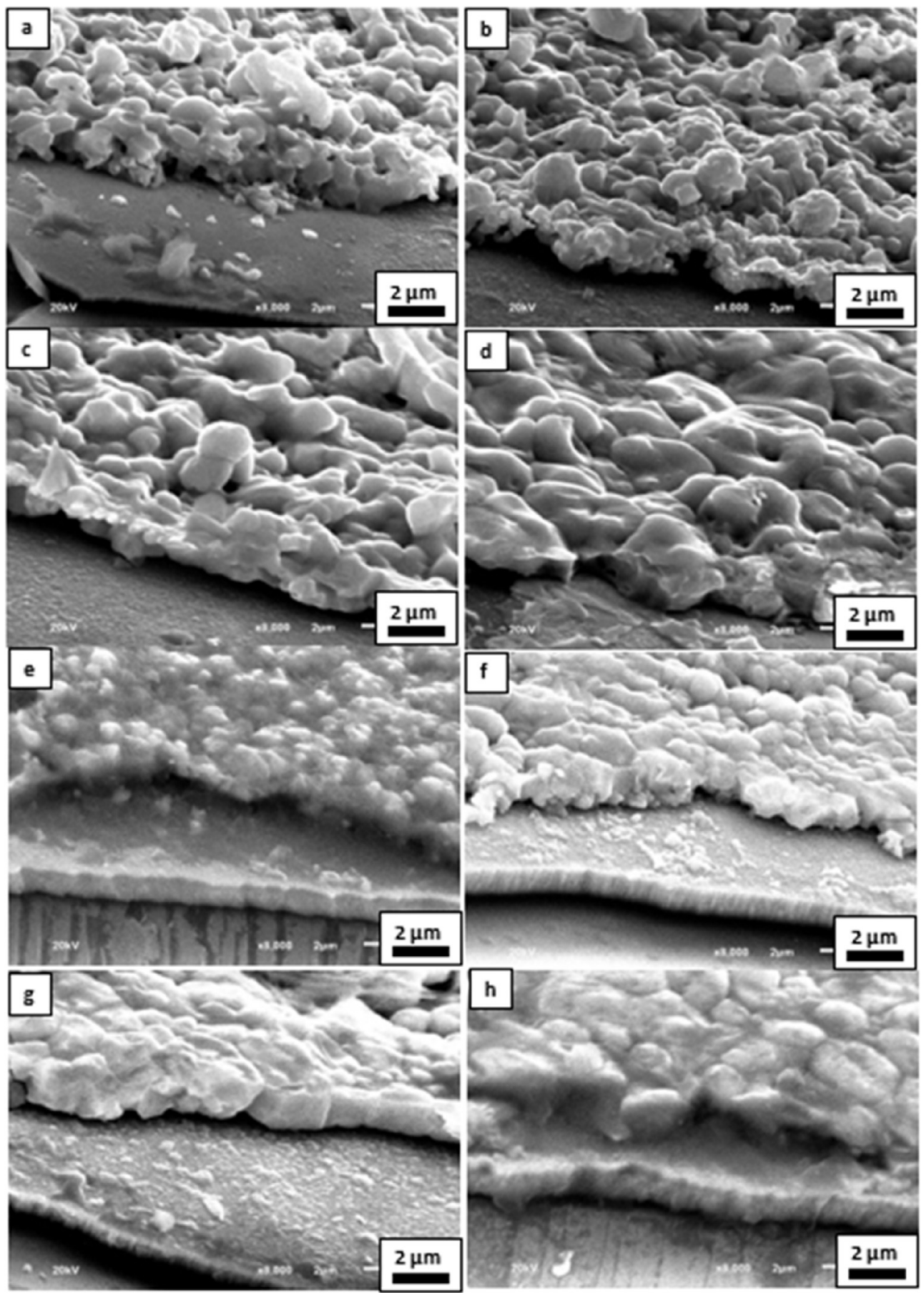

Fig. 5. SEM cross-sectional images of a) A525, b) A550, c) A575, d) A600, e) B525, f) B550, g) B575, and h) B600 samples.

formation of $\left[\mathrm{V}_{\mathrm{Cu}}+\mathrm{Zn}_{\mathrm{Cu}}\right]$ defect clusters give rise to downshift of the valance band maximum and upshift of the conduction band minimum, increasing the bandgap.

All CZTSe thin films exhibited p-type conductivity regardless of the Cu composition. Van der Pauw measurements showed that the "B" type films displayed higher carrier concentration and lower resistivity values. The resistivity values changed from $4.27 \Omega-\mathrm{cm}$ to $4.06 \times 10^{-2} \Omega-\mathrm{cm}$ for the $\mathrm{Cu}$-poor "A" type films, and from $4.27 \times 10^{-1} \Omega$-cm to $4.06 \times 10^{-3} \Omega$-cm for the Cu-rich "B" type films with increasing reaction temperature. The carrier concentration varied from $2.08 \times 10^{16} \mathrm{~cm}^{-3}$ to $2.13 \times 10^{19} \mathrm{~cm}^{-3}$ for the $\mathrm{Cu}$-poor films and it varied from $2.08 \times 10^{17} \mathrm{~cm}^{-3}$ to $2.13 \times 10^{20} \mathrm{~cm}^{-3}$ for the $\mathrm{Cu}$-rich films as the reaction temperature was increased from $525^{\circ} \mathrm{C}$ to $600{ }^{\circ} \mathrm{C}$. These results can be attributed to the presence of secondary $\mathrm{Cu}$-selenide phase in the high temperature (575 and $600{ }^{\circ} \mathrm{C}$ ) composite layers. It has been reported that as the $\mathrm{Cu}-$ selenide phase is removed from the composite films by etching in a KCN solution, the carrier concentration decreases and the resistivity values increase [30]. 


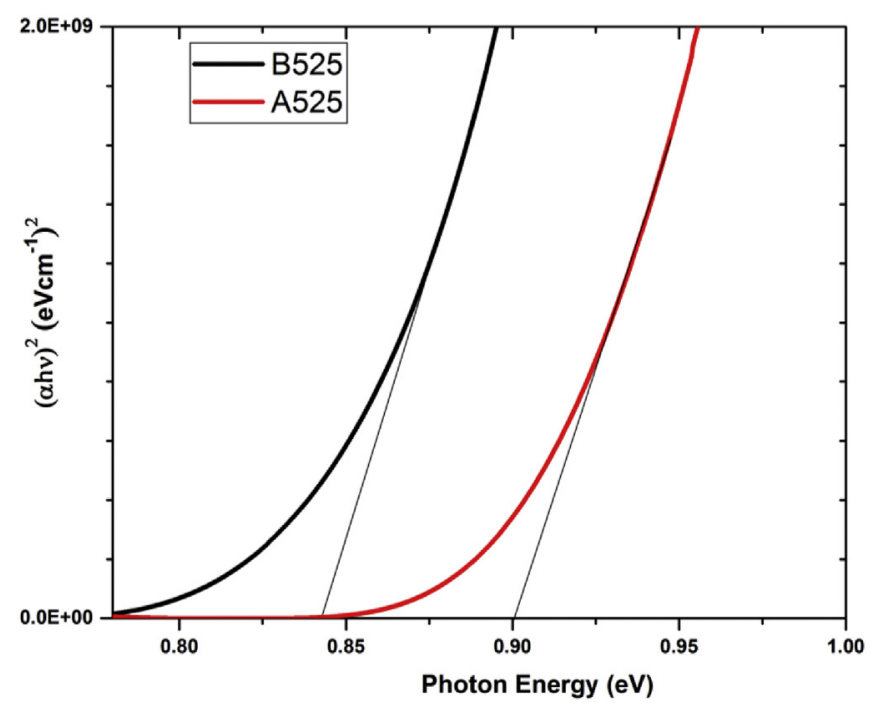

Fig. 6. Plot of $(\alpha h u)^{2}$ versus photon energy (hu) for the estimation of optical band gap energy for the A525 and B525 CZTSe films.

Table 3

Optical band gap values of A and B type CZTSe thin films.

\begin{tabular}{lllll}
\hline Sample ID & \multicolumn{4}{l}{ Cu-poor Cu-rich } \\
\cline { 2 - 5 } & A525 & A550 & B525 & B550 \\
\hline $\mathrm{E}_{\mathrm{g}}(\mathrm{eV})$ & 0.90 & 0.93 & 0.84 & 0.90 \\
\hline
\end{tabular}

\section{Conclusions}

In this study, effects of the $\mathrm{Cu}$ content and the reaction temperature on the structural, optical, and electrical properties of CZTSe kesterite films were presented. The films were grown by reaction of sputter deposited $\mathrm{Cu} / \mathrm{Sn} / \mathrm{Zn} / \mathrm{Cu}$ layers with evaporated Se films at the reaction temperatures of $525,550,575$ and $600{ }^{\circ} \mathrm{C}$ for $15 \mathrm{~min}$ and they all had $\mathrm{Zn}$-rich compositions. A relatively high temperature rise rate of $5{ }^{\circ} \mathrm{C}$ was used for the reaction step. XRD analyses showed the characteristic peaks of kesterite CZTSe for all layers regardless of their $\mathrm{Cu}$ content and the processing temperature. However, for samples reacted at temperatures of $575^{\circ} \mathrm{C}$ and $600{ }^{\circ} \mathrm{Ca} \mathrm{Cu} \mathrm{Cu}_{2-\mathrm{x}}$ Se secondary phase separation was detected for both $\mathrm{Cu}$-poor and $\mathrm{Cu}$-rich samples. Excessive Sn loss was also present in samples processed at these elevated temperatures. Raman scattering measurements confirmed formation of the CZTSe kesterite structure, and also indicated a small ZnSe phase, which could not be detected by XRD. Films with $\mathrm{Cu}$-poor composition were found to have a more ordered crystal structure. Scanning electron micrographs demonstrated dense film structures with the $\mathrm{Cu}$-poor films having rougher morphology. Increasing the $\mathrm{Cu}$ content in the films gave rise to reduced bandgap values, reduced resistivity and increased carrier concentration values. All of our findings are in agreement with the fact that the best solar cells have been fabricated on Cu-poor, Zn-rich CZTSe layers.

\section{Acknowledgement}

The authors wish to express their gratitude to Prof. Dr. Oğuz Doğan and Necmettin Erbakan University for Raman scattering measurements support.

\section{References}

[1] P. Jackson, D. Hariskos, R. Wuerz, W. Wischmann, M. Powalla, Compositional investigation of potassium doped $\mathrm{Cu}(\mathrm{In}, \mathrm{Ga}) \mathrm{Se}_{2}$ solar cells with efficiencies up to $20.8 \%$, Phys. Status Solidi RRL 8 (2014) 219.

[2] S. Siebentritt, S. Schorr, Kesterites- a challenging material for solar cells, Prog. Photovolt. Res. Appl. 20 (2012) 512.

[3] R.A. Wibowo, E.S. Lee, B. Munir, K.H. Kim, Pulsed laser deposition of quaternary $\mathrm{Cu}_{2} \mathrm{ZnSnSe}_{4}$ thin films, Phys. Status Solidi A 204 (10) (2007) 3373.

[4] W. Septina, S. Ikeda, T. Harada, M. Matsumura, Fabrication of $\mathrm{Cu}_{2} \mathrm{ZnSnSe}_{4}$ thin films from an electrodeposited $\mathrm{Cu}-\mathrm{Zn}-\mathrm{Sn}-\mathrm{Se} / \mathrm{Cu}-\mathrm{Sn}-\mathrm{Se}$ bilayer, Phys. Status Solidi C 10 (2013) 1062.

[5] L. Guo, Y. Zhu, O. Gunawan, T. Gokmen, V.R. Deline, S. Ahmed, L.T. Romankiw, H. Deligianni, Electrodeposited $\mathrm{Cu}_{2} \mathrm{ZnSnSe}_{4}$ thin film solar cell with $7 \%$ power conversion efficiency, Prog. Photovolt. Res. Appl. 22 (2014) 58.

[6] W. Dang, X. Ren, W. Zi, L. Jia, S. Liu, Composition controlled preparation of Cu$\mathrm{Zn}-\mathrm{Sn}$ precursor films for $\mathrm{Cu}_{2} \mathrm{ZnSnS}_{4}$ solar cells using pulsed electrodeposition, J. Alloys Comp. 650 (2015) 1-7.

[7] W. Wang, M.T. Winkler, O. Gunawan, T. Gokmen, T.K. Todorov, Y. Zhu, D.B. Mitzi, Device characteristics of CZTSSe thin film solar cells with $12.6 \%$ efficiency, Adv. Energy Mater. 4 (2014) 1301465.

[8] S. Queslati, G. Brammertz, M. Buffiere, H. ElAnzeery, O. Touayar, C. Köble, J. Bekaert, M. Meuris, J. Poortmans, Physical and electrical characterization of high-performance Cu2ZnSnSe4 based thin film solar cells, Thin Solid Films 582 (2015) 224-228.

[9] J. Marquez-Prieto, Y. Ren, R.W. Miles, N. Pearsall, I. Frobes, The influence of precursor $\mathrm{Cu}$ content and two-stage processing conditions on the microstructure of Cu2ZnSnSe4, Thin Solid Films 582 (2015) 220-223.

[10] I. Repins, C. Beall, N. Vora, C. DeHart, D. Kuciauskas, P. Dippo, B. To, J. Mann, W. Hsu, A. Goodrich, R. Noufi, Co-evaporated $\mathrm{Cu}_{2} \mathrm{ZnSnSe}_{4}$ films and devices, Sol. Energy Mater. Sol. Cells 101 (2012) 154.

[11] C.S. Prajapati, A. Kushwaha, P.P. Sahay, Experimental investigation of spraydeposited Fe-doped $\mathrm{ZnO}$ nanoparticle thin films:structural, microstructural, and optical properties, JTTEE5 22 (2013) 1230-1241.

[12] L.C. Chen, C.A. Hsieh, Characterization of CuZnO diodes prepared by ultrasonic spray method, JTTEE5 24 (2015) 1542-1548.

[13] M. Schwartzkopf, A. Buffet, V. Körstgens, E. Metwalli, K. Schlage, G. Benecke, J. Perlich, M. Rawolle, A. Rothkirch, B. Heidmann, G. Herzog, P. MüllerBuschbaum, R. Röhlsberger, R. Gehrke, N. Stribeck, S.V. Roth, From atoms to layers: in situ gold cluster growth kinetics during sputter deposition, Nanoscale 5 (2013) 5053-5062.

[14] M. Schwartzkopf, G. Santoro, C.J. Brett, A. Rothkirch, O. Polonskyi, A. Hinz, E. Metwalli, Y. Yao, T. Strunskus, F. Faupel, P. Müller-Buschbaum, S.V. Roth, Real-time monitoring of morphology and optical properties during sputter deposition for tailoring Metal-Polymer interfaces, ACS Appl. Mater. Interfaces 7 (2015) 13547-13556.

[15] B. Basol, V. Kapur, CuInSe 2 thin films and high efficiency solar cells obtained by selenization of metallic layers, in: Proc. 21st IEEE Photovoltaic Specialists Conference, May 21-25, 1990, p. 546. Kissimmee, FL.

[16] H. Yoo, R. Wibowo, G. Manoharan, R. Lechner, S. Jost, A. Verger, J. Palm, $\mathrm{R}$. Hock, The formation mechanism of secondary phases in $\mathrm{Cu}_{2} \mathrm{ZnSnSe}_{4}$ absorber layer, Thin Solid Films 582 (2015) 245-248.

[17] B. Basol, Electrochemically Deposited CdTe Films and Their Application to Solar Cells, 1980, p. 34. UCLA PhD dissertation.

[18] G.S. Babu, Y.B.K. Kumar, P.U. Bahaskar, V.S. Raja, Effect of post-deposition annealing on the growth of Cu2ZnSnSe4 thin films for a solar cell absorber layer, Semicond. Sci. Technol. 23 (2008) 085023.

[19] Y.H. Jo, B.C. Mohanty, D.H. Yeon, S.M. Lee, Y.S. Cho, Sol. Energy Mater. Sol. Cells 132 (2015) 136-141.

[20] P.M.P. Salome, P.A. Fernandes, A.F. da Cunha, Influence of selenization pressure on the growth of $\mathrm{Cu}_{2} \mathrm{ZnSnSe}_{4}$ films from stacked metallic layers, Phys. Status Solidi C 7 (2010) 913-916.

[21] G. Rey, A. Redinger, J. Sendler, T.P. Weiss, M. Thevenin, M. Guennou, B. El Adib, S. Siebentritt, The band gap of $\mathrm{Cu}_{2} \mathrm{ZnSnSe}_{4}$ : effect of order-disorder, Appl. Phys. Lett. 105 (2014) 112106.

[22] J. Márquez, M. Neuschitzer, M. Dimitrievska, R. Gunder, S. Haass, M. Werner, Y.E. Romanyuk, S. Schorr, N.M. Pearsall, I. Forbes, Systematic compositional changes and their influence on lattice and optoelectronic properties of $\mathrm{Cu}_{2} \mathrm{ZnSnSe}_{4}$ kesterite solar cells, Sol. Energy Mater. Sol. Cells 144 (2016) $579-585$.

[23] M. Paris, L. Choubrac, A. Lafond, C. Guillot-Deudon, S. Jobic, N.M.R. Solid-State Raman spectroscopy to address the local structure of defects and the tricky issue of the $\mathrm{Cu} / \mathrm{Zn}$ disorder in Cu-poor, Zn-rich CZTS materials, Inorg. Chem. 53 (2014) 8646-8653.

[24] S. Chen, X.G. Gong, A. Walsh, S.-H. Wei, Defect physics of the kesterite thinfilm solar cell absorber $\mathrm{Cu}_{2} \mathrm{ZnSnS}_{4}$, Appl. Phys. Lett. 96 (2010) 021902.

[25] G.S. Babu, Y.B.K. Kumar, P.U. Bhaskar, S.R. Vanjari, Effect of $\mathrm{Cu} /(\mathrm{Zn}+\mathrm{Sn})$ ratio on the properties of co-evaporated $\mathrm{Cu}_{2} \mathrm{ZnSnSe}_{4}$ thin films, Sol. Energy Mater. Sol. Cells 94 (2010) 221.

[26] T.M. Friedlmeier, N. Wieser, T. Walter, H. Dittrich, H.W. Schock, Heterojunctions based on $\mathrm{Cu}_{2} \mathrm{ZnSnS}_{4}$ and $\mathrm{Cu}_{2} \mathrm{ZnSnSe}_{4}$ thin films, in: Proceedings of the 14th European Photovoltaic Science and Engineering and Exhibition Conference, Bedford, 1997, p. 1242.

[27] S. Ahn, S. Jung, J. Gwak, A. Cho, K. Shin, K. Yoon, D. Park, H. Cheong, J.H. Yun, 
Determination of band gap energy $\left(E_{g}\right)$ of $\mathrm{Cu}_{2} \mathrm{ZnSnSe}_{4}$ thin films: on the discrepancies of reported band gap values, Appl. Phys. Lett. 97 (2010) 021905.

[28] S. Yazici, M.A. Olgar, F.G. Akca, A. Cantas, M. Kurt, G. Aygun, E. Tarhan, E. Yanmaz, L. Ozyuzer, Growth of $\mathrm{Cu}_{2} \mathrm{ZnSnS}_{4}$ absorber layer on flexible metallic substrates for thin film solar cell applications, Thin Solid Films 589 (2015) 563-573.
[29] Y. Hirate, H. Tampo, S. Minoura, H. Kadowaki, A. Nakane, K.M. Kim, H. Shibata, S. Niki, H. Fujiwara, Dielectric functions of $\mathrm{Cu}_{2} \mathrm{ZnSnS}_{4}$ and $\mathrm{Cu}_{2} \mathrm{SnSe}_{3}$ semiconductors, J. Appl. Phys. 117 (2015) 015702.

[30] T. Tanaka, T. Sueishi, K. Saito, Q. Guo, M. Nishio, K.M. Yu, W. Walukiewicz, Existence and removal of $\mathrm{Cu}_{2} \mathrm{Se}$ second phase in co-evaporated $\mathrm{Cu}_{2} \mathrm{ZnSnSe}_{4}$ thin films, J. Appl. Phys. 111 (2012) 053522. 